\title{
Android-Based Dental and Oral Health Diagnostic Expert System
}

\author{
Marcia Kamila $\mathbf{R}^{1}$, dan Rinabi Tanamal ${ }^{2}$ \\ ${ }^{1,2}$ Information Technology, Universitas Ciputra, Citraland CBD Boulevard, Surabaya \\ e-mail: ${ }^{1}$ ciananda7@gmail.com, ${ }^{2}$ r.tanamal@ ciputra.ac.id
}

\begin{abstract}
Dental and oral health is one of the most crucial things for human health. If it is taken cared properly then all foods will be absorbed optimally and the human body will have all the nutrition needed. Otherwise, if it is not taken care properly then it will affect the health condition of a human body. Lack of awareness of Indonesians about their dental and oral health had caused many infection cases which leads to teeth structural damage. In 2013, Health Research and Development Agency had done a survey based on interview's result. They found that 25,9 percent of people in Indonesia were having issues with their dental and oral health in the last 12 months. Among them, there was 68,8 percent people who had not taken any treatments. To resolve this problem, an expert system with android platform is made to diagnose dental and oral diseases. The research methodology used is forward chaining method. Expert System Shell used is CLIPS which then adopted into Android application.
\end{abstract}

Kata Kunci: Expert System, Forward Chaining, Android, Dental and Oral Diseases.

\section{Introduction}

Oral and dental problems are one of the most-complained diseases by Indonesian people. Dental and oral problems in Indonesia which developed from dental caries occupy the highest rank of $45.68 \%$ and belong to the top ten of diseases suffered by people (Kementerian Kesehatan, 2014). Based on the age category, the youth suffered more caries compared to the age of 45 and above (Norfai \& Rahman, 2017). This high number of dental diseases in Indonesia is caused by a lack of public awareness to maintain dental and oral hygiene. Oral and dental health is a crucial factor in an entire human body. If the health of one's oral or dental is bad, then the impact to general health is profound. For example, toothaches, sprues or even cavities will trouble oral's activity and lose one's appetite which probably will affect another body part's health. There are still many people who have not realized the importance of maintaining oral and dental health so that they became unaware of the impacts and side effects that can emerge by not maintaining their oral and dental health. Besides that, there is also a group of people who recognized it but did not understand it so they did not take care of their oral and dental health properly (Hestieyonini, Kiswaluyo, E.Y, \& Meilawaty, 2013).

Based on the data and information center of the Indonesian Ministry of Health, a simple analysis was carried out to see the level of distribution of dentist health workers at the Health
Center. The result of a simple analysis showed that most health centers in 33 provinces are still troubled with lack of dentist. 3 provinces which "lacking" the most were West Papua, Papua, and North Sulawesi. Compared to the Indonesian population, the dentist ratio from 2009-2013 tends to be around 4-5 dentists per 100.000 population (Kementerian Kesehatan, 2014).

From the data obtained above, it can be seen that the level of public awareness of dental and oral health is still low while the distribution of dentists in Indonesia is also still lacking. Therefore, this research was made with the goal of being able to help the Indonesian people, especially who live in areas that have a lack of dental medical personnel's that are able to identify and diagnose dental and oral diseases. Hopefully, this expert system can provide enough diagnoses and understandings in the matter of the diseases suffered so that prevention, as well as further check-ups, can be done. This expert system is also useful to help medical personnel's such as dentists or dentist' assistants to make a decision when diagnosing their patients.

\section{Research Methodology}

Expert system is commonly known as a Knowledge-Based System which means a computer application with the aim to facilitate decisionmaking or problem-solving in a specific matter. One of the most important components needed for an expert system is knowledge and analytical 
methods that have been defined and explained by an expert who have expertise in certain fields. Function and purpose of the expert system are similar with an expert or person who has numerous knowledge and experience at solving problem, therefore this system is called an expert system (Rukun \& Hayadi, 2016). According to Hayadi (2018), expert system is very popular for their numerous abilities and benefits, that is:

1. Work faster than human that can increase the number of productivity.

2. Using an expert system, common people can work as an expert.

3. Improve quality by giving consistent advice and reducing mistakes.

3. Expert systems have the ability to absorb and conceive knowledge from an expert.

4. Can be used as a training media. Beginners who work with expert system applications could become more experienced and increase knowledge because the expert system acts as a teacher.

5. Improve the ability to solve problems because the expert system takes the source of knowledge from several experts.

There are also some disadvantages to an expert system (Hayadi, 2018), that is:

1. Cost for manufacturing and maintenance that tend to be expensive.

2. Hard to develop because of limited expertise and availability of experts in certain fields.

3. Expert system is not $100 \%$ accurate.

Expert system consists of several concepts that must be owned (Rukun \& Hayadi, 2016). The basic concepts of an expert system are:

\section{Expertise}

Expertise is special knowledge obtained from a training and learning process in a particular field.

Knowledge can be in the form of facts, theories, rules or global strategies to solve problems.

\section{Experts}

Expert is someone who has knowledge in a certain field. An expert can usually recognize and solve problems correctly in order to explain the solutions to the problem.

3. Transferring Expertise

This process can be translated as the process of transferring knowledge of experts to the system. This knowledge then be placed in a component called the knowledge-base. This process has a purpose so that it can be used by other people who are not experts (common people).

4. Interference Rule
This process includes procedures to resolve problems which carried out by inference machines.

5. Rule

Rules are needed because the majority of the expert system are rule-based systems, which means that knowledge is stored as rules.

6. Explanation Capability

Ability to explain is a characteristic of an expert system that can explain well and giving advice on recommended actions.

In an expert system, there are two inference methods called Forward Chaining and Backward Chaining.

a. Forward Chaining

Forward chaining method is a searching methodology or a tracking technique in a forward pattern which started from the existing information and rule combining to result in a conclusion or purpose (Rukun \& Hayadi, 2016). The operation of forward chaining method begins by inserting a set of known facts into working memory, then transcribing new facts based on regulation which the premise fits the known facts (Rukun \& Hayadi, 2016).

b. Backward Chaining

Backward Chaining is a reverse reasoning method of forward chaining. Backward trace method starts reasoning with the result then traces back to the path that will lead to the result. Backward chaining can also be called goal-driven reasoning (Hutagalung \& Hutahean, 2015).

For this research, forward chaining method is applied. Forward chaining method is implemented in a decision tree. A decision tree is one of the techniques that can be applied to clarify a set of objects or records. This technique consists of some decision-tree which connected by downmoving branches starting from a node and ended on a leaf node. Each branch can be entered either into another decision node or leaf node (Hadi, 2017).

To get information from experts, the researcher is using observation and interview method. Observation method can be done by observing behavior, incident or activity of the inspected person or groups of people (Djaelani, 2013). By those activities then the observation's results are recorded to find out what really happened. With observation, researchers can see through the events as the inspected subject experienced, caught and felt the phenomenon according to the subject's understanding as well as 
the inspected objects (Djaelani, 2013). An interview is a meeting of two people to share information and ideas to each other by asking and answering so that meaning from a certain topic can be constructed (Sugiyono, 2012).

\section{Discussion}

\subsection{System Design}

There is system architecture made to show how an expert system application work that can be seen at Image 1. First, the application will display several questions related to symptoms of the disease while the users have to answer these questions according to their conditions. Second, the application will process the data input (symptoms and conditions) from the user, which then adjusted to knowledge-base that has been made. Third, the application will display conclusion based on facts entered by users, the conclusion shown is the type of disease suffered, details and explanation about the disease, and a treatment plan that can be done by users to overcome the disease.

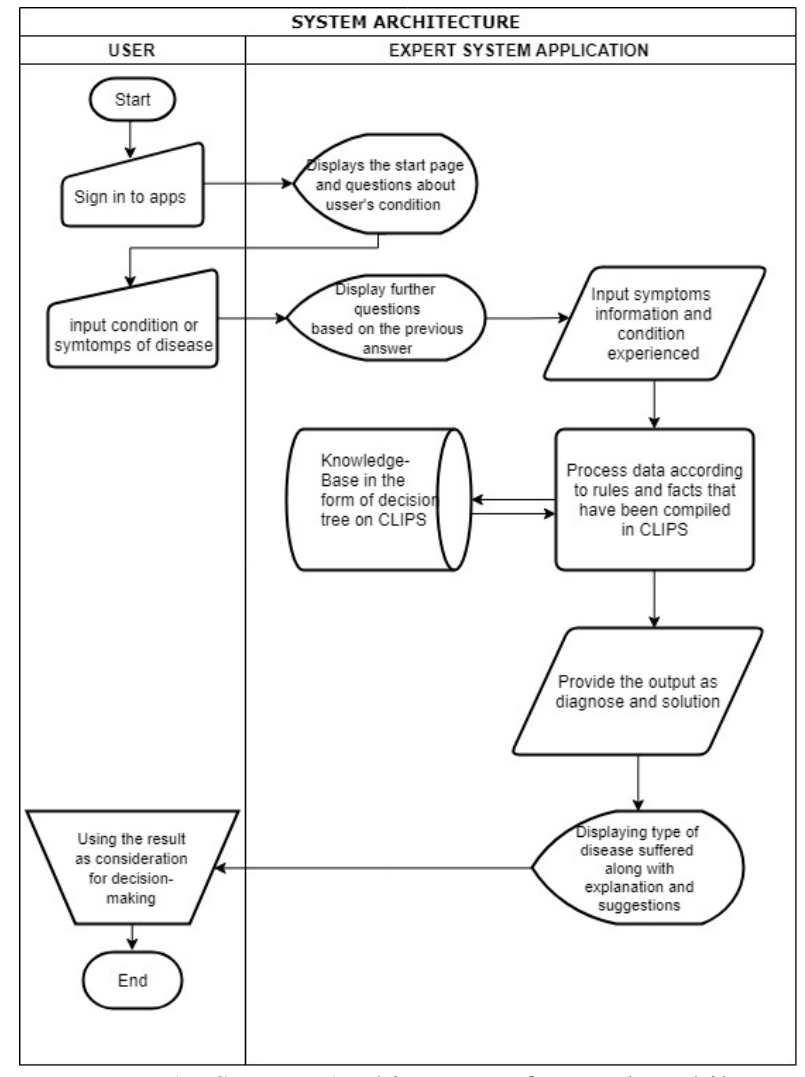

Image 1. System Architecture of Dental Mobile

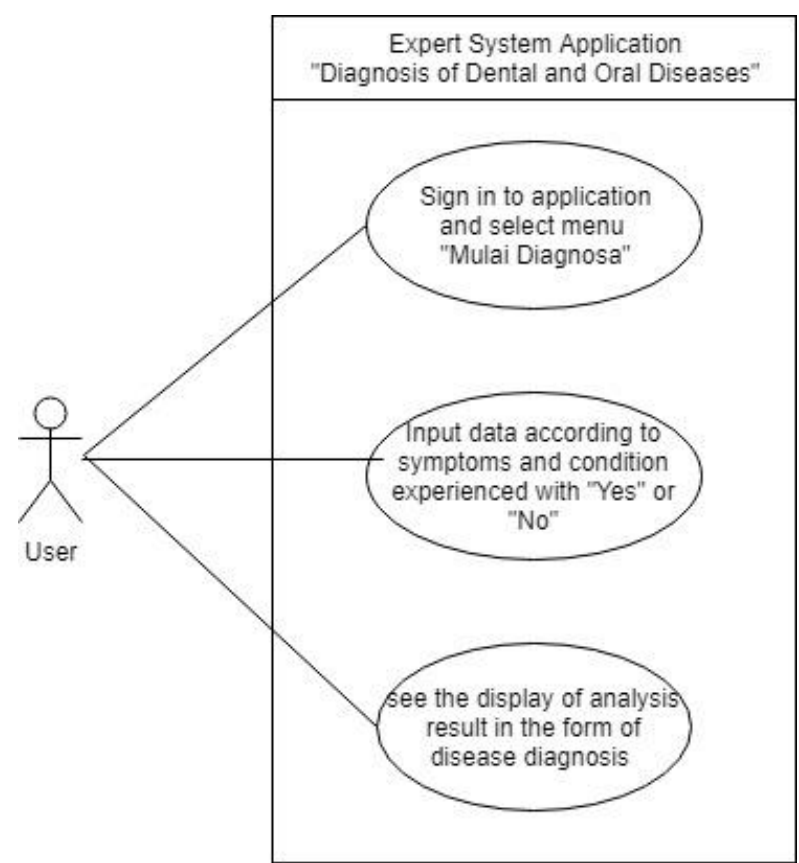

Image 2. Use Case Diagram

Use case diagram is a description of a system that will be created with an interaction between actor and systems. The purpose of making use case diagram is to be able to know all of the functions or features owned by the system and who can use those features. Use case diagrams dan help explain briefly about user's perspective on the function of a system.

\subsection{Decision Tree Implementation}

Information and knowledge from interview's result obtained then arranged in the form of a decision tree. According to Hadi (2017), Decision Tree is a technique that can be used to classify a set of object or records. This technique consists of a collection of decision trees that are connected by branching node which then move downward from node to the leaf node. There are 3 types of nodes in a decision tree (Hadi, 2017), those are:

a. Root Node

Root Node is the node located at the top of the decision tree. This node has no input and can also have no output, but it is possible to have more than one output.

b. Internal Node

Internal Node is a branching node. This node has only one type of input and has at least two outputs.

b. Leaf Node

Leaf Node is the final node. In this node, there will only be one type of input with no output.

Table 1 is an explanation of the decision tree that has been made. The decision tree can be 
seen in the attachment at the end of this article.

Table 1 Decision Tree of Disease Diagnosis

\begin{tabular}{|c|c|c|}
\hline No & Questions & $\begin{array}{l}\text { Results of } \\
\text { Analysis }\end{array}$ \\
\hline 1 & $\begin{array}{l}\text { Is the pain or problem } \\
\text { located on your teeth } \\
\text { and gum? }\end{array}$ & $\begin{array}{l}\text { (Yes) Continues } \\
\text { to question } 2 \\
\text { (No) Continues to } \\
\text { question } 22\end{array}$ \\
\hline 2 & $\begin{array}{l}\text { Is there any plaque } \\
\text { between your teeth and } \\
\text { gum? }\end{array}$ & $\begin{array}{l}\text { (Yes) Continues } \\
\text { to question } 3 \\
\text { (No) Continues to } \\
\text { question } 12\end{array}$ \\
\hline 3 & $\begin{array}{l}\text { Does your gum bleed } \\
\text { easily? }\end{array}$ & $\begin{array}{l}\text { (Yes) Continues } \\
\text { to question } 4 \\
\text { (No) Chronic } \\
\text { Marginal } \\
\text { Gingivitis }\end{array}$ \\
\hline 4 & $\begin{array}{l}\text { Do your teeth } \\
\text { wobbling? }\end{array}$ & $\begin{array}{l}\text { (Yes) Continues } \\
\text { to question } 5 \\
\text { (No) Continues to } \\
\text { question } 8\end{array}$ \\
\hline 5 & $\begin{array}{l}\text { Does your gum feel } \\
\text { itchy? }\end{array}$ & $\begin{array}{l}\text { (Yes) Continues } \\
\text { to question } 6 \\
\text { (No) Continues to } \\
\text { question } 7\end{array}$ \\
\hline 6 & Does the gum hurt? & $\begin{array}{l}\text { (Yes) Acute } \\
\text { Marginal } \\
\text { Periodontitis } \\
\text { (No) Chronic } \\
\text { Marginal } \\
\text { Periodontitis }\end{array}$ \\
\hline 7 & Does the gum hurt? & $\begin{array}{l}\text { (Yes) Acute } \\
\text { Apical } \\
\text { Periodontitis } \\
\text { (No) Chronic } \\
\text { Apical } \\
\text { Periodontitis }\end{array}$ \\
\hline 8 & Are you in pregnancy? & $\begin{array}{l}\text { (Yes) Pregnancy } \\
\text { Gingivitis (dental } \\
\text { plaque) } \\
\text { (No) Continues to } \\
\text { question } 9\end{array}$ \\
\hline 9 & $\begin{array}{l}\text { Do you have a smoking } \\
\text { habit? }\end{array}$ & $\begin{array}{l}\text { (Yes) Systemic } \\
\text { Gingivitis in } \\
\text { Smokers (dental } \\
\text { plaque) } \\
\text { (No) Continues to } \\
\text { question } 10 \\
\end{array}$ \\
\hline 10 & $\begin{array}{l}\text { Do you have any } \\
\text { records of diabetes? }\end{array}$ & $\begin{array}{l}\text { (Yes) Diabetes } \\
\text { Systemic } \\
\text { Gingivitis (dental } \\
\text { plaque) } \\
\text { (No) Continue to } \\
\text { question } 11\end{array}$ \\
\hline 11 & $\begin{array}{l}\text { Does the body } \\
\text { temperature is high? }\end{array}$ & $\begin{array}{l}\text { (Yes) ANUG } \\
\text { (No) Acute } \\
\text { Marginal } \\
\text { Gingivitis }\end{array}$ \\
\hline
\end{tabular}

\begin{tabular}{|c|c|c|}
\hline 12 & $\begin{array}{l}\text { Are there any cavities } \\
\text { on teeth? }\end{array}$ & $\begin{array}{l}\text { (Yes) Continues } \\
\text { to question } 13 \\
\text { (No) Continues to } \\
\text { question } 17\end{array}$ \\
\hline 13 & $\begin{array}{l}\text { Do the teeth feel } \\
\text { painful at night? }\end{array}$ & $\begin{array}{l}\text { (Yes) Continues } \\
\text { to question } 14 \\
\text { (No) Continues to } \\
\text { question } 15\end{array}$ \\
\hline 14 & $\begin{array}{l}\text { Do the teeth feel } \\
\text { painful while being } \\
\text { pressed? }\end{array}$ & $\begin{array}{l}\text { (Yes) Totalis Pulp } \\
\text { Necrosis } \\
\text { (No) Parsialis } \\
\text { Pulpa Necrosis }\end{array}$ \\
\hline 15 & $\begin{array}{l}\text { Does the teeth in } \\
\text { prolonged pain? }\end{array}$ & $\begin{array}{l}\text { (Yes) Profunda } \\
\text { Caries } \\
\text { (No) Continues to } \\
\text { question } 16\end{array}$ \\
\hline 16 & $\begin{array}{l}\text { Does the pain on teeth } \\
\text { last for } 1 / 2-1 \text { minute } \\
\text { after it was exposed to } \\
\text { hot, cold food, } \\
\text { drinks/after brushing } \\
\text { teeth? }\end{array}$ & $\begin{array}{l}\text { (Yes) Media } \\
\text { Caries } \\
\text { (No) Superficial } \\
\text { Caries }\end{array}$ \\
\hline 17 & Does the gum hurt? & $\begin{array}{l}\text { (Yes) Continues } \\
\text { to question } 18 \\
\text { (No) Continues to } \\
\text { question } 21\end{array}$ \\
\hline 18 & Are you in pregnancy? & $\begin{array}{l}\text { (Yes) Pregnancy } \\
\text { Gingivitis (dental } \\
\text { plaque) } \\
\text { (No) Continues to } \\
\text { question } 19\end{array}$ \\
\hline 19 & $\begin{array}{l}\text { Do you have a smoking } \\
\text { habit? }\end{array}$ & $\begin{array}{l}\text { (Yes) Systemic } \\
\text { Gingivitis in } \\
\text { Smokers (with no } \\
\text { dental plaques) } \\
\text { (No) Continues to } \\
\text { question } 20\end{array}$ \\
\hline 20 & $\begin{array}{l}\text { Do you have any } \\
\text { records of diabetes? }\end{array}$ & $\begin{array}{l}\text { (Yes) Diabetes } \\
\text { Systemic } \\
\text { Gingivitis (with } \\
\text { no dental plaques) } \\
\text { (No) Chronic } \\
\text { Marginal } \\
\text { Gingivitis }\end{array}$ \\
\hline 21 & $\begin{array}{l}\text { Do the teeth feel } \\
\text { painful after it was } \\
\text { exposed to hot, cold, } \\
\text { food/after brushing } \\
\text { teeth? }\end{array}$ & $\begin{array}{l}\text { (Yes) Superficial } \\
\text { Caries } \\
\text { (No) Gingivitis }\end{array}$ \\
\hline 22 & $\begin{array}{l}\text { Does the problem occur } \\
\text { on the tongue? }\end{array}$ & $\begin{array}{l}\text { (Yes) Continues } \\
\text { to question } 23 \\
\text { (No) Continues to } \\
\text { question } 28\end{array}$ \\
\hline 23 & $\begin{array}{l}\text { Does the tongue look } \\
\text { reddish? }\end{array}$ & $\begin{array}{l}\text { (Yes) Continues } \\
\text { to question } 24 \\
\text { (No) Continues to } \\
\text { question } 26\end{array}$ \\
\hline
\end{tabular}




\begin{tabular}{|c|c|c|}
\hline 24 & $\begin{array}{l}\text { Does the tongue feel } \\
\text { painful and burning? }\end{array}$ & $\begin{array}{l}\text { (Yes) Glossitis } \\
\text { (No) Continues to } \\
\text { question } 25\end{array}$ \\
\hline 25 & $\begin{array}{l}\text { Is there any pattern } \\
\text { which looks like a map } \\
\text { on the tongue? }\end{array}$ & $\begin{array}{l}\text { (Yes) Geographic } \\
\text { Tongue } \\
\text { (No) Tongue } \\
\text { Infection }\end{array}$ \\
\hline 26 & $\begin{array}{l}\text { Does the tongue look } \\
\text { pale? }\end{array}$ & $\begin{array}{l}\text { (Yes) Candidiasis } \\
\text { (No) Continues to } \\
\text { question } 27\end{array}$ \\
\hline 27 & $\begin{array}{l}\text { Does the tongue look } \\
\text { blackish/other than } \\
\text { blackish and has hair? }\end{array}$ & $\begin{array}{l}\text { (Yes) Hairy } \\
\text { tongue } \\
\text { (No) Tongue } \\
\text { Infection }\end{array}$ \\
\hline 28 & $\begin{array}{l}\text { Is there any disease on } \\
\text { oral cavity and cheeks? }\end{array}$ & $\begin{array}{l}\text { (Yes) Continues } \\
\text { to question } 29 \\
\text { (No) Oral } \\
\text { cavity/cheeks } \\
\text { infection }\end{array}$ \\
\hline 29 & $\begin{array}{l}\text { Does the oral } \\
\text { cavity/cheeks hurt? }\end{array}$ & $\begin{array}{l}\text { (Yes) Continues } \\
\text { to question } 30 \\
\text { (No) Continues to } \\
\text { question } 33\end{array}$ \\
\hline 30 & $\begin{array}{l}\text { Is there any white } \\
\text { round-shaped wound } \\
\text { and clustering? }\end{array}$ & $\begin{array}{l}\text { (Yes) Ulser } \\
\text { (virus) } \\
\text { (No) Continues to } \\
\text { question } 31 \\
\end{array}$ \\
\hline 31 & $\begin{array}{l}\text { Is there any white } \\
\text { round-shaped wound } \\
\text { (not clustered)? }\end{array}$ & $\begin{array}{l}\text { (Yes) Continues } \\
\text { to question } 32 \\
\text { (No) Oral } \\
\text { cavity/cheeks } \\
\text { infection }\end{array}$ \\
\hline 32 & $\begin{array}{l}\text { Does the location of the } \\
\text { wound move } \\
\text { frequently? }\end{array}$ & $\begin{array}{l}\text { (Yes) RAS } \\
\text { (No) Ulser (local) }\end{array}$ \\
\hline 33 & $\begin{array}{l}\text { Are there any white } \\
\text { lines on cheeks? }\end{array}$ & $\begin{array}{l}\text { (Yes) Linea Alba } \\
\text { Bukalis } \\
\text { (No) Not in scope }\end{array}$ \\
\hline
\end{tabular}

\subsection{Implementation into CLIPS}

The process of implementation into software expert system CLIPS aims to test patterns and steps of question and answers from decision tree that was previously made. $C$ Language Integrated Production System (CLIPS) is an expert system shell program that can be used to develop an expert system (Kumar, 2015). CLIPS stores memory or data including a list of facts, rules or regulation and module to activate those rules.

Here are some code fragments for CLIPS expert system programming terms along with the results of the dialog window:

a. Initial Initialization Stage

(defrule inisialisasi
(initial-fact)
$=>$

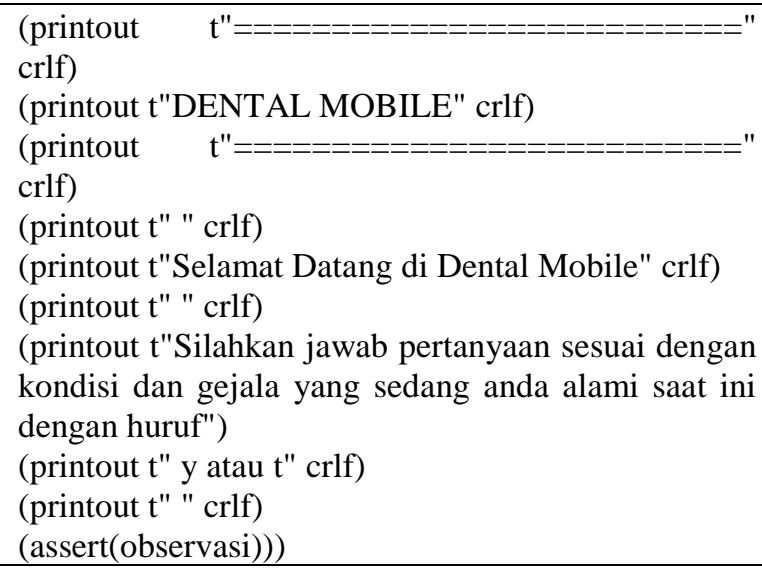

b. Rule

(defrule ruleP01
(observasi)

$\Rightarrow$

(printout t"Apakah masalah atau penyakit terdapat di bagian gigi dan gusi? (y/t)"crlf)

(assert(P01(read))

(printout t" " crlf))

c. Result

(defrule resultD01

(P03 t)

$=>$

(printout t"Kemungkinan Diagnosa Penyakit anda adalah" crlf)

(printout t"GINGIVITIS MARGINALIS KRONIS" crlf)

(printout t"Penyakit ini adalah radang pada gusi (lanjutan dari penyakit gingivitis marginalis akut) biasanya pada penyakit ini, gusi tidak terasa sakit dan tidak mudah berdarah" crlf)

(printout t" " crlf)

(printout t"Rencana perawatan yang mungkin dilakukan adalah scalling (pembersihan karang gigi/kalkulus)" crlf)

(printout t"silahkan melakukan pemeriksaan lebih lanjut ke dokter gigi" crlf)

(printout t" " crlf))

\section{d. Dialog Window}

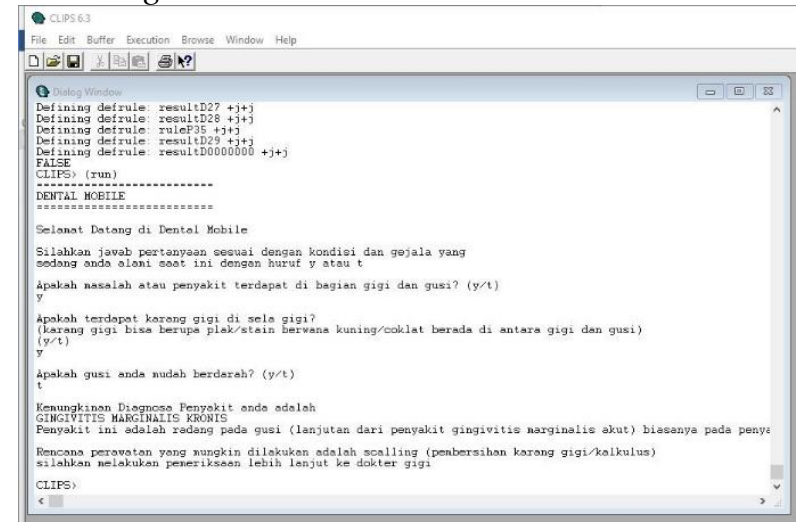

Image 3. An example of CLIPS software expert system program's usage simulation 


\subsection{Implementation into Android application}

The process of this application making is completed with the support of platform app inventor called MIT App Inventor. MIT App Inventor provides a platform to develop Androidbased application and stores the work's result into the cloud so the application which still in progress cannot be lost. To create an application, researcher started from making the design of display/userinterface first on App Inventor Designer part. After the display is completed, the researcher then switched to App Inventor Blocks Editor part where coding /programming can be done by compiling a block program which provided by MIT App Inventor. Here are the final results of oral and dental health diagnostic expert system application:

\section{a. First Page}

Consisting of some features which started from diagnosis, how to use and about us. To begin with the main feature, users can reach to "start diagnosis" feature, to see usage's procedure users can reach to "how to use" feature and about us feature is as an introduction from application creator.

Image 4. Application main menu

\section{b. Question Page}

On this page, users can answer the question according to the symptoms or their current conditions. This page includes a visual to help users on deciding their disease condition.

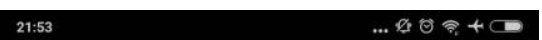

Langkah 2

Apakah terdapat karang gigi di sela gigi? (karang gigi bisa berupa plak/stain berwarna putih/kuning/coklat berada di antara gigi dan gusi)

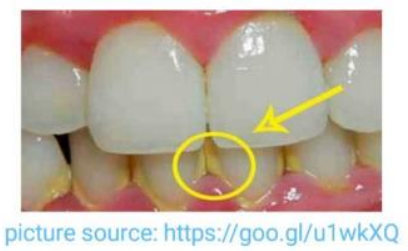

\section{Ya}

Tidak

Kembali ke pertanyaan sebelumnya

Image 5. Question page

\section{c. Diagnosis Page}

Diagnosis page is the final result of this expert system application. This page consists of disease diagnosis, explanation, and suggestion of treatment's plan.

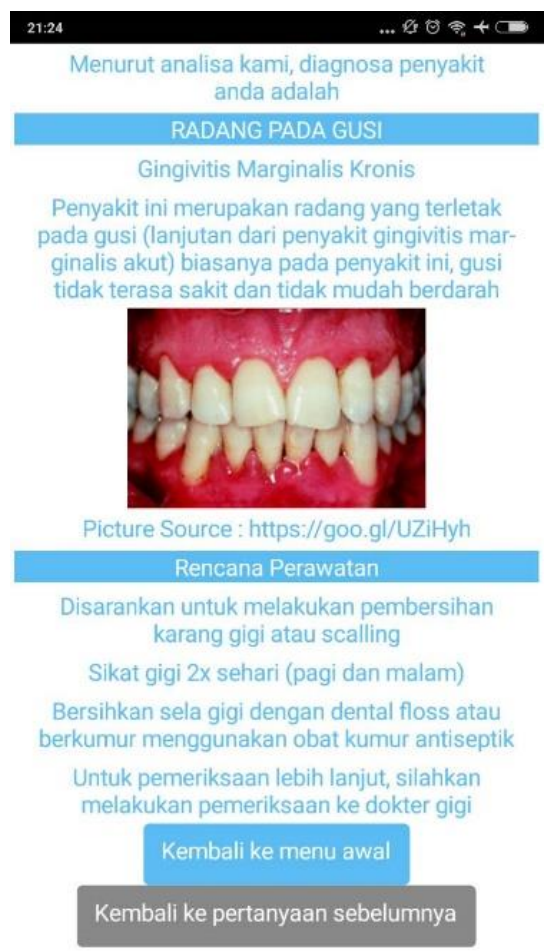

Image 6. Disease diagnosis analysis result page 


\subsection{Accuracy Test}

The accuracy test is done by comparing analysis result of the expert system applied to the real events happened in the field. To do the accuracy test, the researcher was ensuring analysis result with the help of dentists. The test was done by trying out the application based on the symptoms suffered by patients. Here is a table of diagnostic comparison results:

Table 2 Accuracy Test

\begin{tabular}{|c|c|c|c|}
\hline Symptoms & $\begin{array}{l}\text { Applica- } \\
\text { tion } \\
\text { analysis } \\
\text { results }\end{array}$ & $\begin{array}{l}\text { Dentist } \\
\text { analysis } \\
\text { results }\end{array}$ & $\begin{array}{c}\text { Cor- } \\
\text { respo } \\
\text { nding/ } \\
\text { not }\end{array}$ \\
\hline $\begin{array}{l}\text {-Teeth and gum } \\
\text {-Dental plaque } \\
\text { exists } \\
\text {-Gum bleeds } \\
\text { easily } \\
\text {-Wobbly teeth } \\
\text {-Itchy gum } \\
\text {-Painful gum }\end{array}$ & $\begin{array}{l}\text { Acute } \\
\text { Marginal } \\
\text { Periodon- } \\
\text { titis }\end{array}$ & $\begin{array}{l}\text { Acute } \\
\text { Marginal } \\
\text { Periodon- } \\
\text { titis }\end{array}$ & $\begin{array}{l}\text { Corres } \\
\text { pon- } \\
\text { ding }\end{array}$ \\
\hline $\begin{array}{l}\text {-Teeth and gum } \\
\text {-Dental plaque } \\
\text { exists } \\
\text {-Gum bleeds } \\
\text { easily } \\
\text {-Wobbly teeth } \\
\text {-Painless gum }\end{array}$ & $\begin{array}{l}\text { Chronic } \\
\text { Marginal } \\
\text { Periodon- } \\
\text { titis }\end{array}$ & $\begin{array}{l}\text { Chronic } \\
\text { Marginal } \\
\text { Periodon- } \\
\text { titis }\end{array}$ & $\begin{array}{l}\text { Corres } \\
\text { pon- } \\
\text { ding }\end{array}$ \\
\hline $\begin{array}{l}\text {-Teeth and gum } \\
\text {-Dental plaque } \\
\text { exists } \\
\text {-Gum bleeds } \\
\text { easily } \\
\text {-Wobbly teeth } \\
\text {-Non-itchy gum } \\
\text {-Painless gum }\end{array}$ & $\begin{array}{l}\text { Chronic } \\
\text { Apical } \\
\text { Periodon- } \\
\text { titis }\end{array}$ & $\begin{array}{l}\text { Chronic } \\
\text { Apical } \\
\text { Periodon- } \\
\text { titis }\end{array}$ & $\begin{array}{l}\text { Corres } \\
\text { pon- } \\
\text { ding }\end{array}$ \\
\hline $\begin{array}{l}\text {-Teeth and gum } \\
\text {-Dental plaque } \\
\text { exists } \\
\text {-Gum bleeds } \\
\text { easily } \\
\text {-In a pregnancy }\end{array}$ & $\begin{array}{l}\text { Pregnancy } \\
\text { Gingivitis }\end{array}$ & $\begin{array}{l}\text { Pregnancy } \\
\text { Gingivitis }\end{array}$ & $\begin{array}{l}\text { Corres } \\
\text { pon- } \\
\text { ding }\end{array}$ \\
\hline $\begin{array}{l}\text {-Teeth and gum } \\
\text {-Dental plaque } \\
\text { or stain exists } \\
\text {-Gum bleeds } \\
\text { easily } \\
\text {-Smoking habit }\end{array}$ & $\begin{array}{l}\text { Smokers } \\
\text { Systemic } \\
\text { Gingivitis }\end{array}$ & $\begin{array}{l}\text { Smokers } \\
\text { Systemic } \\
\text { Gingivitis }\end{array}$ & $\begin{array}{l}\text { Corres } \\
\text { pon- } \\
\text { ding }\end{array}$ \\
\hline $\begin{array}{l}\text {-Teeth and gum } \\
\text {-Dental plaque } \\
\text { exists } \\
\text {-Gum bleeds } \\
\text { easily }\end{array}$ & $\begin{array}{l}\text { Diabetes } \\
\text { Systemic } \\
\text { Gingivitis }\end{array}$ & $\begin{array}{l}\text { Diabetes } \\
\text { Systemic } \\
\text { Gingivitis }\end{array}$ & $\begin{array}{l}\text { Corres } \\
\text { pon- } \\
\text { ding }\end{array}$ \\
\hline
\end{tabular}

\begin{tabular}{|c|c|c|c|}
\hline $\begin{array}{l}\text {-There is a } \\
\text { record of } \\
\text { diabetes }\end{array}$ & & & \\
\hline $\begin{array}{l}\text {-Teeth and gum } \\
\text {-No dental } \\
\text { plaques } \\
\text {-Gum bleeds } \\
\text { easily } \\
\text {-There is a } \\
\text { record of } \\
\text { diabetes }\end{array}$ & $\begin{array}{l}\text { Diabetes } \\
\text { Systemic } \\
\text { Gingivitis } \\
\text { (with no } \\
\text { dental } \\
\text { plaques) }\end{array}$ & $\begin{array}{l}\text { Diabetes } \\
\text { Systemic } \\
\text { Gingivitis } \\
\text { (with no } \\
\text { dental } \\
\text { plaques) }\end{array}$ & $\begin{array}{l}\text { Corres } \\
\text { pon- } \\
\text { ding }\end{array}$ \\
\hline $\begin{array}{l}\text {-Teeth and gum } \\
\text {-No dental } \\
\text { plaques } \\
\text {-Gum bleeds } \\
\text { easily } \\
\text {-Smoking habit }\end{array}$ & $\begin{array}{l}\text { Smokers } \\
\text { Systemic } \\
\text { Gingivitis } \\
\text { (with no } \\
\text { dental } \\
\text { plaques) } \\
\end{array}$ & $\begin{array}{l}\text { Smokers } \\
\text { Systemic } \\
\text { Gingivitis } \\
\text { (with no } \\
\text { dental } \\
\text { plaques) } \\
\end{array}$ & $\begin{array}{l}\text { Corres } \\
\text { pon- } \\
\text { ding }\end{array}$ \\
\hline $\begin{array}{l}\text {-Teeth and gum } \\
\text {-No dental } \\
\text { plaques } \\
\text {-Gum bleeds } \\
\text { easily } \\
\text {-In a pregnancy }\end{array}$ & $\begin{array}{l}\text { Pregnancy } \\
\text { Gingivitis } \\
\text { (with no } \\
\text { dental } \\
\text { plaques) }\end{array}$ & $\begin{array}{l}\text { Pregnancy } \\
\text { Gingivitis } \\
\text { (with no } \\
\text { dental } \\
\text { plaques) }\end{array}$ & $\begin{array}{l}\text { Corres } \\
\text { pon- } \\
\text { ding }\end{array}$ \\
\hline $\begin{array}{l}\text {-Teeth and gum } \\
\text {-Gum bleeds } \\
\text { easily } \\
\text {-Dental plaque } \\
\text { exists } \\
\text {-High body } \\
\text { temperature }\end{array}$ & ANUG & ANUG & $\begin{array}{l}\text { Corres } \\
\text { pon- } \\
\text { ding }\end{array}$ \\
\hline $\begin{array}{l}\text {-Teeth and gum } \\
\text {-Dental plaque } \\
\text { exists } \\
\text {-Gum bleeds } \\
\text { easily }\end{array}$ & $\begin{array}{l}\text { Acute } \\
\text { Marginal } \\
\text { Gingivitis }\end{array}$ & $\begin{array}{l}\text { Acute } \\
\text { Marginal } \\
\text { Gingivitis }\end{array}$ & $\begin{array}{l}\text { Corres } \\
\text { pon- } \\
\text { ding }\end{array}$ \\
\hline $\begin{array}{l}\text {-Teeth and gum } \\
\text {-Dental plaque } \\
\text { exists } \\
\text {-Gum does not } \\
\text { bleed easily }\end{array}$ & $\begin{array}{l}\text { Chronic } \\
\text { Marginal } \\
\text { Gingivitis }\end{array}$ & $\begin{array}{l}\text { Chronic } \\
\text { Marginal } \\
\text { Gingivitis }\end{array}$ & $\begin{array}{l}\text { Corres } \\
\text { pon- } \\
\text { ding }\end{array}$ \\
\hline $\begin{array}{l}\text {-Teeth and gum } \\
\text {-There is cavity } \\
\text {-Painful teeth at } \\
\text { night } \\
\text {-Painful teeth } \\
\text { while being } \\
\text { pressed }\end{array}$ & $\begin{array}{l}\text { Totalis } \\
\text { Pulp } \\
\text { Necrosis }\end{array}$ & $\begin{array}{l}\text { Totalis } \\
\text { Pulp } \\
\text { Necrosis }\end{array}$ & $\begin{array}{l}\text { Corres } \\
\text { pon- } \\
\text { ding }\end{array}$ \\
\hline $\begin{array}{l}\text {-Teeth and gum } \\
\text {-There is cavity } \\
\text {-Painful teeth at } \\
\text { night } \\
\text {-Teeth are not } \\
\text { painful while } \\
\text { being pressed }\end{array}$ & $\begin{array}{l}\text { Parsialis } \\
\text { Pulp } \\
\text { Necrosis }\end{array}$ & $\begin{array}{l}\text { Parsialis } \\
\text { Pulp } \\
\text { Necrosis }\end{array}$ & $\begin{array}{l}\text { Corres } \\
\text { pon- } \\
\text { ding }\end{array}$ \\
\hline
\end{tabular}




\begin{tabular}{|c|c|c|c|}
\hline $\begin{array}{l}\text {-Teeth and gum } \\
\text {-There is cavity } \\
\text {-Teeth are in } \\
\text { prolonged pain }\end{array}$ & $\begin{array}{l}\text { Profunda } \\
\text { Caries }\end{array}$ & $\begin{array}{l}\text { Profunda } \\
\text { Caries }\end{array}$ & $\begin{array}{l}\text { Corres } \\
\text { pon- } \\
\text { ding }\end{array}$ \\
\hline $\begin{array}{l}\text {-Teeth and gum } \\
\text {-There is cavity } \\
\text {-Teeth feel } \\
\text { painful for } \\
\text { about } 1-1 / 2 \\
\text { minutes when } \\
\text { exposed to } \\
\text { heat/cold }\end{array}$ & $\begin{array}{l}\text { Media } \\
\text { Caries }\end{array}$ & $\begin{array}{l}\text { Media } \\
\text { Caries }\end{array}$ & $\begin{array}{l}\text { Corres } \\
\text { pon- } \\
\text { ding }\end{array}$ \\
\hline $\begin{array}{l}\text {-Teeth and gum } \\
\text {-There is cavity } \\
\text {-Teeth only feel } \\
\text { painful when } \\
\text { exposed to } \\
\text { heat/cold }\end{array}$ & $\begin{array}{l}\text { Superfici- } \\
\text { al Caries }\end{array}$ & $\begin{array}{l}\text { Superfici- } \\
\text { al Caries }\end{array}$ & $\begin{array}{l}\text { Corres } \\
\text { pon- } \\
\text { ding }\end{array}$ \\
\hline $\begin{array}{l}\text {-Tongue } \\
\text {-Reddish } \\
\text { tongue } \\
\text {-Feels painful } \\
\text { and burning }\end{array}$ & Glossitis & Glossitis & $\begin{array}{l}\text { Corres } \\
\text { pon- } \\
\text { ding }\end{array}$ \\
\hline $\begin{array}{l}\text {-Tongue } \\
\text {-Reddish } \\
\text { tongue } \\
\text {-Painless } \\
\text {-There is a map } \\
\text { pattern }\end{array}$ & $\begin{array}{l}\text { Geogra- } \\
\text { phic } \\
\text { Tongue }\end{array}$ & $\begin{array}{l}\text { Geogra- } \\
\text { phic } \\
\text { Tongue }\end{array}$ & $\begin{array}{l}\text { Corres } \\
\text { pon- } \\
\text { ding }\end{array}$ \\
\hline
\end{tabular}

\subsection{User Acceptance Test}

This test is tested on users. With the number of 20 respondents. Users were asked to try using the application and fill out the questionnaire regarding the performance and benefits of the application. The test is conducted using a Likert scale assessment. The assessed aspects include in terms of user experience, understanding of instructions given, user-interface display and usefulness of the main features of the application.

Table 3 Likert Scale Questionnaire

\begin{tabular}{|c|l|c|c|c|c|c|c|}
\hline \multirow{2}{*}{ No } & \multicolumn{1}{|c|}{ Questions } & \multicolumn{5}{|c|}{ User Rating } & Per- \\
\cline { 3 - 7 } & & 1 & 2 & 3 & 4 & 5 & $\begin{array}{c}\text { cent } \\
\text { age }\end{array}$ \\
\hline 1 & $\begin{array}{l}\text { The application is } \\
\text { easy to understand }\end{array}$ & & & 1 & 13 & 6 & $85 \%$ \\
\hline 2 & $\begin{array}{l}\text { The application is } \\
\text { easy to use }\end{array}$ & & 1 & 7 & 12 & $91 \%$ \\
\hline 3 & $\begin{array}{l}\text { Information and } \\
\text { instruction given } \\
\text { in the application } \\
\text { are easy to } \\
\text { understand }\end{array}$ & & 3 & 8 & 9 & $86 \%$ \\
\hline 4 & $\begin{array}{l}\text { User-interface } \\
\text { display of the the }\end{array}$ & & 6 & 11 & 3 & $77 \%$ \\
\hline
\end{tabular}

\begin{tabular}{|l|l|l|l|l|l|l|l|}
\hline & $\begin{array}{l}\text { application is } \\
\text { attractive }\end{array}$ & & & & & & \\
\hline 5 & $\begin{array}{l}\text { The application is } \\
\text { useful }\end{array}$ & & 3 & 5 & 12 & $89 \%$ \\
\hline
\end{tabular}

The conclusions can be drawn as follows, for the first statement on the ease of application to be understood gets a satisfaction percentage of $85 \%$, second statement on the ease of application to be used gets percentage of $91 \%$, third statement which is instruction application and how to use the application gets percentage of $86 \%$, fourth statement on interface display gets percentage of $77 \%$, and the last statement on the benefits of expert system application for users gets the percentage of $90 \%$.

\section{Conclusion}

Conclusions that can be drawn from the whole process that has been undertaken are:

a. From the results of interviews and observation by experts and researcher, a decision tree can be constructed which then implemented into the CLIPS software expert system and Android application.

b. The accuracy level of dental disease diagnostic expert system application's analysis result to the history of patients status on the field is already conformable.

c. From the results of the User Acceptance Test can be known that this oral and dental health diagnostic expert system Application is useful for commoners.

\section{Future Work}

There are also some suggestions obtained from the results of this expert system test. These suggestions needed to improve the future work of application. The suggestions are:

a. To upgrade display design so that it would not look too rigid and flat.

b. To add more features so that users who have or do not have any dental problems can experience the advantages better. The example of the feature to add is in the form of suggestion or preventive steps to prevent future dental problems.

c. To give more understanding on medical terms displayed.

d. To add more interesting visuals to attract users attention. 


\section{Bibliography}

Djaelani, A. R. (2013, Maret 1). Teknik Pengumpulan Data Dalam Penelitian Kualitatif. Majalah Ilmiah Pawiyatan, hal. 84-86.

Hadi, F. (2017). Penerapan Data Mining dalam Menganalisa Pemberian Pinjaman Dengan Menggunakan Metode Algoritma C5.0 (Studi Kasus: Koperasi Jasa Keuangan Syariah Kelurahan Lambung Bukik). Jurnal KomTekInfo, 215.

Hayadi, B. H. (2018). Sistem Pakar. Yogyakarta: Deepublish.

Hestieyonini, H., Kiswaluyo, E.Y, R. W., \& Meilawaty, Z. (2013). Perilaku Menjaga Kesehatan Gigi dan Mulut pada Santri Pondok Pesantren AlAzhar Jember. Bagian Ilmu Kesehatan Gigi Masyarakat, 17.

Hutagalung, J. E., \& Hutahean, J. (2015). Sistem Pakar Dengan Metode Backward Chaining Untuk Pengujian Transistor di Laboratorium Elektronika. Riau Journal of Computer Science, 9-10.

Kementerian Kesehatan, R. I. (2014, September 12). Diambil kembali dari Kementerian Kesehatan Republik http://www.depkes.go.id/article/view/1502180 0002/situasi-kesehatan-gigi-dan-mulut.html

Kumar, S. (2015). Imporrtance of Expert System Shell in Development of Expert System. International Journal of Innnovative Research \& Development, 130.

Norfai, \& Rahman, E. (2017, Juli 1). Hubungan Pengetahuan dan Kebiasaan Menggosok Gigi dengan Kejadian Karies Gigi di SDI Darul Mu'Minin Kota Banjarmasin Tahun 2017. Dinamika Kesehatan, hal. 213.

Program Studi Sistem Informasi Fakultas Sains dan Teknologi Universitas Ma Chung. (2018). Studi Kasus Sistem Berbasis Pengetahuan. Malang: Seribu Bintang.

Pusat Data dan Informasi Kementrian Kesehatan RI. (2014). Situasi Kesehatan Gigi dan Mulut. Bulan Kesehatan Gigi Nasional, 5.

Rukun, K., \& Hayadi, B. H. (2016). Sistem Informasi Berbasis Expert System. Yogyakarta: Deepublish.

Sugiyono. (2012). Metode Penelitian Kuantitatif, Kualitatif, dan R\&D. Bandung: PT.Remaja Rosdakarya.

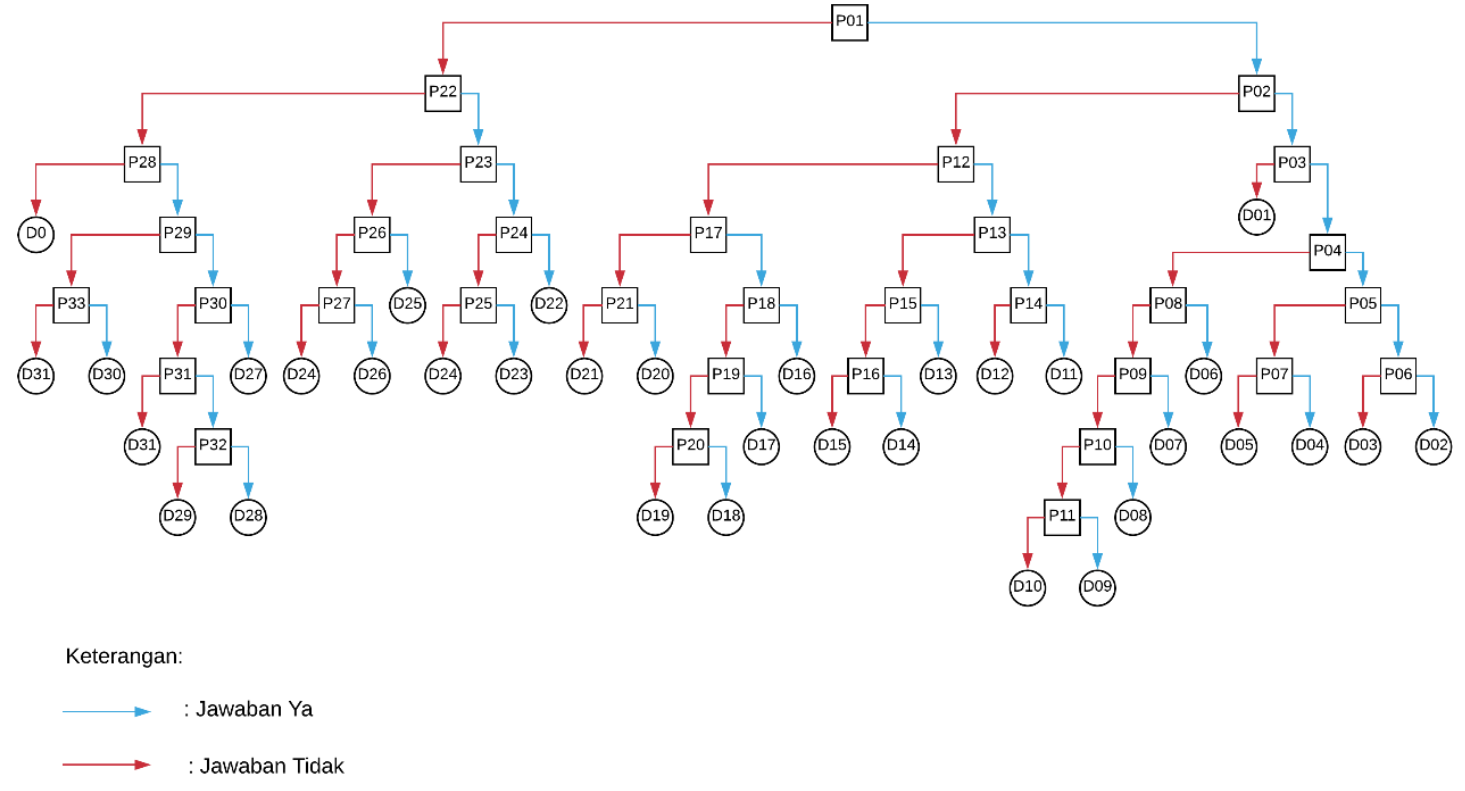

Attachment : Decision Tree Diagram 